\title{
Effects of inducible nitric oxide synthase and xanthine oxidase inhibitors on SEB-induced interstitial pneumonia in mice
}

\author{
H. Miyakawa, K. Sato, T. Shinbori, T. Okamoto, Y. Gushima, M. Fujiki, M. Suga
}

\begin{abstract}
Effects of inducible nitric oxide synthase and xanthine oxidase inhibitors on SEB-induced interstitial pneumonia in mice. H. Miyakawa, K. Sato, T. Shinbori, T. Okamoto, Y. Gushima, M. Fujiki, M. Suga. (C) ERS Journals Ltd 2002.

ABSTRACT: The authors have previously reported that intratracheal instillation of staphylococcal enterotoxin-B (SEB) induced interstitial pneumonia (IP) in autoimmune-prone mice. SEB-reactive T-cells were critically involved in the development of IP in this model. Concern has arisen about the hazards of reactive oxygen species (ROS) and reactive nitrogen species (RNS) in the process of lung injury and fibrosis.

Therefore, the involvement of nitric oxide (NO) and superoxide anion $\left(\mathrm{O}_{2}^{-}\right)$in the pathogenesis of IP in this autoimmune-prone model has been investigated.

Nitrite/nitrate levels were increased in bronchoalveolar lavage (BAL) fluid and serum from SEB-injected mice. The signal of the NO-(N-(dithiocarboxy) sarcosine $)_{2-}$ $\mathrm{Fe}^{2+}$ complex was detected in the SEB-injected lung and whole blood by electron paramagnetic resonance (EPR) spectroscopy. NO production was significantly decreased by aminoguanidine (AG) treatment. Xanthine oxidase (XO) activity in the lung, BAL fluid, and plasma was increased with instillation of SEB, and 4-amino-6hydroxypyrazolo(3,4-d)-pyrimidine (AHPP) significantly inhibited XO activity. Moreover, both AG and AHPP significantly decreased production of pro-inflammatory cytokines, numbers of infiltrated cells in BAL fluid, and the area of thickened alveolar septa in the SEB-injected lung.

In conclusion, the overproduction of nitric oxide and super oxide anion were implicated in the pathogenesis of interstitial pneumonia, and inducible nitric oxide synthase and xanthine oxidase inhibitors had protective effects against interstitial pneumonia in this model.
\end{abstract}

Eur Respir J 2002; 19: 447-457.
First Dept of Internal Medicine, Kumamoto University School of Medicine, Kumamoto, Japan.

Correspondence: M. Suga

First Dept of Internal Medicine

Kumamoto University School of

Medicine

1-1-1 Honjo

Kumamoto 860-0811

Japan

Fax: 81963710582

E-mail: suga@gpo.kumamoto-u.ac.jp

Keywords: Autoimmune disease inducible nitric oxide synthase interstitial pneumonia superantigen xanthine oxidase

Received: July 312001 Accepted after revision November 29 2001

This work was supported by a grant-inaid for interstitial lung disease from the Ministry of Health, Labour and Welfare, Japan.
Several types of interstitial pneumonia (IP) are associated with autoimmune disease [1-3]. Although the pathogenesis of autoimmune disease remains unknown, genetic and environmental factors are known to be contributing factors [4]. A current theory of the pathogenesis of IP emphasizes the role of alveolitis. Alveolitis associated with IP in autoimmune disease is characterized by an increase in both neutrophils and alveolar macrophages [5].

Upon binding to a particular T-cell receptor (TCR) VB chain, bacterial superantigens, such as staphylococcal enterotoxin-B (SEB), trigger T-cell activation, regardless of the TCR $\alpha$-chain partner or TCR specificity [6]. A much larger proportion of T-cells react to superantigens than to conventional antigens. The MRL- $+/+$ mouse strain, which carries the wild-type Fas gene, develops a systemic lupus erythematosus-like disease [7]. The authors have previously reported pulmonary involvement in these mice following administration of SEB [8]. Intratracheal instillation of SEB induced more severe IP in autoimmune-prone MRL- $+/+$ mice than in mice not prone to autoimmunity. These results support the notion that SEB-induced IP is triggered when the host's immune system is activated, and recently, it was shown that SEB-reactive T-cells in the bronchoalveolar space triggered development of IP in this autoimmune-prone model [9]. Furthermore, increases in lymphocytes, alveolar macrophages and neutrophils in the bronchoalveolar lavage (BAL) fluid were found in this model.

There has been an explosion of papers in the past few years arguing that both reactive oxygen species (ROS) and reactive nitrogen species (RNS) are involved in the pathogenesis of lung injury and fibrosis. Nitric oxide (NO) is a gaseous free radical derived from molecular oxygen and the guanidino nitrogen of L-arginine in a reaction catalyzed by NO synthase (NOS) [10]. At least three NOS genes have been cloned: one for neuronal NOS (nNOS), one for inducible NOS (iNOS), and one for endothelial NOS (eNOS). iNOS is not normally expressed in macrophages, fibroblasts, T-helper 1 lymphocytes (Th1), and neutrophils. However, when these cells are activated by specific cytokines, iNOS is upregulated $[10,11]$. Early studies demonstrated that murine macrophages produce NO, suggesting that it may be important in immunity [12]. Extensive circumstantial 
evidence suggests that NO can function as a mediator of tissue damage in autoimmune diseases [13, 14]. For example, in MRL-lpr/lpr mice, which spontaneously develop a lupus-like syndrome, an iNOS inhibitor prevented the development of glomerulonephritis and reduced the intensity of inflammatory arthritis [14].

Studies on the effect of NO on SEB-induced shock have reached conflicting conclusions. SARAWAR et al. [15] showed that aminoguanidine (AG), an iNOS inhibitor, protected against SEB-induced shock in lymphocytic choriomeningitis virus-infected mice. On the contrary, FlorQuin et al. [16] reported that endogenous NO produced after SEB administration had protective effects, since treatment with an iNOS inhibitor dramatically increased the mortality rate in $\mathrm{BALB} / \mathrm{c}$ mice.

The authors hypothesize that the alveolar epithelial cell-injury that characterizes IP associated with autoimmune disease may result, at least in part, from enhanced oxidative and nitrosative stress, which may exist in the lower respiratory tract. Therefore, the effects of an iNOS and a xanthine oxidase (XO) inhibitor on SEB-induced IP in MRL- $+/+$ mice was evaluated. It was found that both $\mathrm{NO}$ and superoxide anion $\left(\mathrm{O}_{2}^{-}\right)$were overproduced, and that inhibitors of iNOS and XO have protective effects in the development of IP in this model. These results suggest that elevated $\mathrm{NO}$ and $\mathrm{O}_{2}^{-}$production is important in the disease manifestation of autoimmune-associated IP and that treatments that block the production of $\mathrm{NO}$ or $\mathrm{O}_{2}^{-}$could be clinically valuable.

\section{Materials and methods}

\section{Staphylococcal enterotoxin-B administration}

SEB (Sigma Chemical Co., St Louis, MO, USA) was instilled into the tracheas of 12-week-old, specific pathogen-free MRL-+/+ mice (Japan SLC, Shizuoka, Japan) as previously described [8]. Briefly, after each mouse was anaesthetized and the trachea was exposed, 40 or $2 \mu \mathrm{g}$ of SEB in $40 \mu \mathrm{L}$ of PBS, or $40 \mu \mathrm{L}$ of phosphate buffered saline (PBS) alone was instilled on day 0 .

Treatment of stapylococcal enterotoxin-B-instilled mice with xanthine oxidase or inducible nitric oxide synthase inhibitors

SEB-instilled mice were given 4-amino-6hydroxypyrazolo(3,4-d)-pyrimidine (AHPP: Acros Organics, Geel, Belgium) orally at $1.0 \mathrm{mg} \cdot \mathrm{mouse}^{-1}$ in $0.2 \mathrm{~mL}$ of $0.1 \mathrm{M} \mathrm{NaOH}$, every day from the day before SEB administration and continuing throughout the course of the experiment. Mice given oral doses of $0.2 \mathrm{~mL}$ of $0.1 \mathrm{M} \mathrm{NaOH}$ served as controls. In a separate experiment, instilled mice were given i.p. $100 \mathrm{mg} \cdot \mathrm{kg}^{-1} \mathrm{AG}$ in $0.2 \mathrm{~mL}$ of saline twice a day at the same time points that AHPP was administered. A control group for AG treatment was given $0.2 \mathrm{~mL}$ of saline i.p. twice a day.

\section{Quantitative histopathology}

Lung tissue was removed 7 days after intratracheal instillation of $2 \mu \mathrm{g}$ SEB and fixed-inflated to $20 \mathrm{cmH}_{2} \mathrm{O}$ pressure with $6 \%$ formalin. After fixation, all lung lobes were cut sagittally through the centre. Tissue sections were stained with haematoxylin-eosin or azan. Alveolar septa that were thickened with interstitial inflammation and fibroblast proliferation were one of the pathological features in this model [8]. The area of thickened and inflamed tissue in comparison to the total area of each lobe was measured using NIH image to calculate the areas of pathological change. Areas of thickened alveolar septa were expressed as a percentage.

\section{Measurement of nitritelnitrate in serum and bronchoalveolar lavage fluid}

Concentrations of nitrite/nitrate in deproteinized serum and BAL fluid were quantified with an autoanalyser system (TCI-NOX 1000; Tokyo Chemical Industry, Tokyo, Japan) by detection of a diazo compound formed in a flow reactor with Griess reagent, as described previously [17].

\section{Measurement of nitric oxide production by electron paramagnetic resonance spectroscopy}

NO production in the mouse lung and whole blood was determined by analysis of NO-(N(Dithiocarboxy) sarcosine (DTCS) $)_{2}-\mathrm{Fe}^{2+}$ complex production (Dojindo Laboratories, Kumamoto, Japan)). The (DTCS $)_{2}-\mathrm{Fe}^{2+}$ complex is formed de novo in tissue after administration of DTCS and $\mathrm{FeSO}_{4}$ in mice. Electron paramagnetic reconance (EPR) spectroscopy was performed as previously described [18]. On day 3 after SEB injection, $\mathrm{FeSO}_{4}$ solution and DTCS were given to mice subcutaneously and i.p., respectively, $30 \mathrm{~min}$ before the removal of plasma, lung, and whole blood for EPR measurement. Samples kept in liquid nitrogen were then subjected to EPR measurement with an X-band EPR spectrometer (ESP380E; Bruker Instrument Inc., Rheinstetten, Germany) at $110 \mathrm{~K}$. Absolute concentrations of the signal height of $\mathrm{NO}-(\mathrm{DTCS})_{2}-\mathrm{Fe}^{2+}$ were determined by double integration of the EPR spectrum, and a $1.0 \mathrm{mM}$ Tempol solution was used as a primary standard for the EPR spectrum. The intensity of the EPR signal was assessed for each $\mathrm{NO}-(\mathrm{DTCS})_{2}-\mathrm{Fe}^{2+}$ complex by measuring the signal height from the baseline to the trough at the field of $\mathrm{g}=2.025$. In general, the signal height of EPR spectra strictly reflects the concentration of each radical species, e.g. of the NO-iron complexes formed.

\section{Immunohistochemistry}

Lung tissue was removed from mice 3 days after intratracheal instillation of $40 \mu \mathrm{g}$ SEB and fixedinflated to $20 \mathrm{cmH}_{2} \mathrm{O}$ pressure with $6 \%$ formalin. 
After dehydration, $3 \mu \mathrm{m}$ thick paraffin sections were cut, deparaffinized and subjected to immunostaining. Sections were then stained with either anti-iNOS antibody (Wako, Osaka, Japan) at 1:500 dilution or anti-nitrotyrosine antibody (Upstate Biotechnology, Lake Placid, NY, USA) at 1:100 dilution, and detection was by an indirect immunoperoxidase method with peroxidase-labelled anti-rabbit immunoglobulin (DAKO, Glostrup, Denmark) diluted 1:100. Peroxidase activity was visualized with the use of $3,3^{\prime}-$ diaminobenzidine as the substrate.

\section{Assay of xanthine oxidase and xanthine} dehydrogenase activity

$\mathrm{XO}$ and xanthine dehydrogenase (XD) activities were assayed by a fluorometric method described previously [19]. The samples were then subjected to a fluorometric assay for $\mathrm{XO} / \mathrm{XD}$ activity with pterine (Sigma Chemical Co.) as the substrate. Isoxantopterin (Aldrich Chemical Co., Milwaukee, WI, USA), a reaction product, was measured with a spectrofluorometer (F-4500; Hitachi Ltd, Tokyo, Japan) with excitation at $345 \mathrm{~nm}$ and emission at $390 \mathrm{~nm}$. The activity was expressed as $\mathrm{nmol}$ isoxantopterin $\cdot \mathrm{min}^{-1} \cdot \mathrm{mL}^{-1}$ of plasma, supernatant of BAL fluid (s-BAL), or total lung homogenates.

Evaluation of inducible nitric oxide synthase and xanthine oxidaselxanthine dehydrogenase messenger ribonucleic acid levels in bronchoalveolar lavage cells

iNOS and XO/XD messenger ribonucleic acid (mRNA) expressions were evaluated by semiquantitative reverse transcription-polymerase chain reaction (RT-PCR) assay. mRNA was extracted with a Micro-FastTrack ${ }^{\mathrm{TM}} 2.0$ kit (Invitrogen Corporation, Carlsbad, CA, USA), according to the manufacturer's instructions. First-strand complementary deoxyribonucleic acid (cDNA) was synthesized by reverse transcriptase.

PCR amplication was performed with specific synthesized primers (Gibco-BRL, Life Technologies, Rockville, MD, USA). Each cycle comprised $1 \mathrm{~min}$ at $94^{\circ} \mathrm{C}$ for denaturation, 2 min at $54^{\circ} \mathrm{C}$ for annealing, and $3 \mathrm{~min}$ at $72^{\circ} \mathrm{C}$ for extension. Prior to and following thermal cycling, the PCR reactions were incubated at $95^{\circ} \mathrm{C}$ for $10 \mathrm{~min}$ and at $72^{\circ} \mathrm{C}$ for $5 \mathrm{~min}$, respectively. For internal control, $\beta$-actin was amplified to normalize the starting amount of cDNA for each sample. The following primers were used: iNOS, 5'-CCCTTCCGAAGTTTCTGGCAGCAGCGGC-3' (sense) and 5'-GGCTGTCAGAGCCTCGTGGCTTTGG-3' (antisense); XO/XD, 5'-CAGGGTCTTGGTCTTTTCAC-3' (sense) and 5'-CGTTGGTTTCAGCGTCAGGA-3' (antisense); and $\beta$-actin, 5'-AGGGTGTGATGGTGGGAATG$3^{\prime}$ (sense) and 5'-GGCTGGGGTGTTGAAGGTCTC-3' (antisense). Twenty-eight cycles were used for $\beta$-actin, 38 cycles were used for iNOS and $\mathrm{XO} /$ $\mathrm{XD}$. The band intensities were determined by NIH image and the iNOS or $\mathrm{XO} / \mathrm{XD}$ to $\beta$-actin ratios were calculated (densitometric ratio of iNOS or $\mathrm{XO} /$ XD mRNA levels).

Quantitative analysis of nitric oxide synthase-inducing activity

BAL was performed with Krebs-Ringer phosphate buffer ( $\mathrm{pH}$ 7.4). The iNOS-inducing ability of s-BAL fluid from mice was tested by stimulating a mouse macrophage cell line, RAW 264 (American Type Culture Collection, Rockville, MD, USA), in culture, as described previously [20]. Specifically, 250, 100, or $50 \mu \mathrm{L}$ of s-BAL fluid from the mice treated with or without SEB was added to the culture of RAW 264 in 24 well-plates with a final volume of $500 \mu \mathrm{L}$ of Dulbecco's modified Eagle's medium F:12 (DMEM/ F12: Gibco-BRL) and 10\% foetal bovine serum. The culture supernatant was obtained $48 \mathrm{~h}$ after stimulation and was subjected to the nitrite/nitrate assay previously described.

\section{Tumour necrosis factor- $\alpha$, interleukin- $1 \beta$, and interferon- $\gamma$ levels in bronchoalveolar lavage fluid}

Tumour necrosis factor- $\alpha$ (TNF- $\alpha)$, interleukin-1 $\beta$ (IL-1 $\beta$ ), and interferon- $\gamma$ (IFN- $\gamma$ ) levels in s-BAL fluid were assayed with a commercially available TNF- $\alpha$, IL-1 $\beta$, or IFN- $\gamma$ enzyme-linked immunoabsorbent assay (ELISA) system (BioSource International Inc., Camarillo, CA, USA).

\section{Statistical analysis}

Values are reported as mean \pm SEM. The unpaired $\mathrm{t}$-test was used to analyse differences between groups. Differences were considered significant at $\mathrm{p}<0.05$.

\section{Results}

Effects of aminoguanadine and 4-amino-6hydroxypyrazolol $(3,4-d)$-pyrimidine on pathological changes of the staphylococcal enterotoxin- $B$ injected lung

To evaluate the involvement of $\mathrm{NO}$ and $\mathrm{O}_{2}{ }^{-}$in the pathogenesis of IP in SEB-instilled MRL- $+/+$ mice, AG (iNOS inhibitor) and AHPP (XO inhibitor) were used as potential therapeutic agents.

Cell infiltration into the alveolar septal wall and the synthesis of pulmonary collagen fibres was decreased with both AG and AHPP treatment (fig. 1). The area in which the alveolar septa was thickened with inflammatory cells and fibroblasts was decreased with AG and AHPP treatment (fig. 2e).

There was a significant increase in total cells in BAL fluid (day 3) between mice injected with SEB $\left(9.2 \times 10^{5} \mathrm{~mL}^{-1}\right)$ and control mice $\left(1.20 \times 10^{5} \mathrm{~mL}^{-1}\right)$ (fig. $2 \mathrm{a}, \mathrm{p}<0.001)$. The numbers of total cells, macrophages, and lymphocytes in BAL fluid from SEBinstilled mice were also decreased with AG and AHPP treatment. These findings suggest that $\mathrm{NO}$ and $\mathrm{O}_{2}^{-}$ 

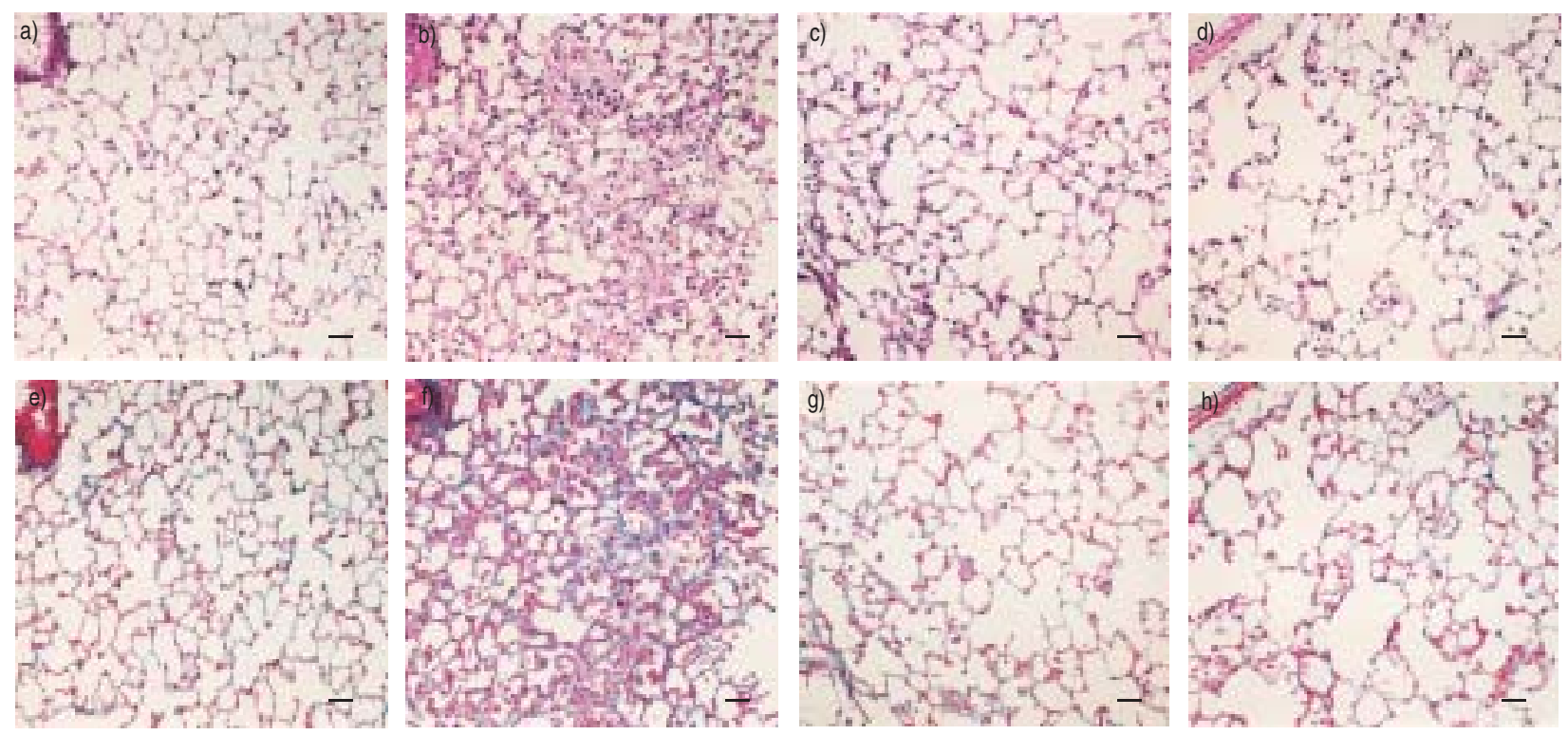

Fig. 1.- Lung sections from control and staphylococcal enterotoxin-B (SEB)-instilled mice under various treatments. Lung tissues obtained from phosphate-buffered saline (PBS)-instilled mice $(\mathrm{a}, \mathrm{e})$ and SEB-instilled mice with saline/NaOH treatment (b, f), with aminoguanidine (AG) treatment (c, g), and with 4-amino 6-hydroxypyrazolo- (3,4-d)-pyrimidine (AHPP) treatment (d, h) were obtained on day 7. Tissues were stained with haematoxylin and eosin $(\mathrm{a}-\mathrm{d})$ and azan $(\mathrm{e}-\mathrm{h})$. Significant inflammatory cell infiltration and synthesis of collagen fibres in the alveolar septal walls are seen in the lung tissue from the SEB-injected mice (b, f). With AG and AHPP treatment, the inflammatory cell infiltration and synthesis of collagen fibres reduced (c, g and $\mathrm{d}, \mathrm{h}$ ). Internal scale bar=50 $\mu \mathrm{m}$.

play critical roles in the pathogenesis of IP in the SEBinstilled MRL-+/+ mice. In addition, the inhibitors of $\mathrm{NO}$ and $\mathrm{O}_{2}^{-}$may be potential therapeutic agents for IP. To determine whether such a therapeutic protection is feasible, the production of $\mathrm{NO}$ and $\mathrm{O}_{2}^{-}$and the effect of inhibitors on this production were examined.

\section{Release of nitric oxide in the staphylococcal enterotoxin-B instilled mice}

To evaluate the involvement of NO in the SEBinduced IP model, NO production was measured by the Griess and EPR methods. The time course of production of NO metabolites (nitrite/nitrate) in the BAL fluid and serum from SEB-instilled mice is shown in figures $3 a$ and $b$. Overall, the amounts of nitrite/nitrate in s-BAL fluid and serum increased in the SEB-instilled mice. BAL fluid nitrite/nitrate levels peaked 3 days after SEB instillation (19.27士 $0.74 \mu \mathrm{M})$ and were significantly higher than peak levels in PBS-instilled mice $(11.84 \pm 1.70 \mu \mathrm{M} ; \mathrm{p}<0.001)$. Similarly, serum nitrite/nitrate levels peaked on day 3 and were significantly higher in SEB-instilled mice than in the control mice $(131.55 \pm 14.8 \mu \mathrm{M}$ versus $19.8 \pm 2.81 \mu \mathrm{M} ; \mathrm{p}<0.001)$.

Levels of nitrite/nitrate in both BAL fluid and serum from SEB-instilled mice $(\mathrm{p}<0.001)$ did not differ from control levels when AG was administered, and there was no inhibitory effect on nitrite/nitrate production with administration of AHPP (figs. 3c and d).

Using EPR spectroscopy, the characteristic superfine structure signals of NO-haemoglobin and NO-haeme complex in the lung and whole blood samples from SEB-instilled mice were detected (data not shown). To increase sensitivity, (DTCS $)_{2}-\mathrm{Fe}^{2+}$ complex was used as a spin trapping agent for NO detection (fig. 4). After treatment with DTCS and $\mathrm{FeSO}_{4}$, a strong EPR signal indicative of NO(DTCS $)_{2}-\mathrm{Fe}^{2+}$ complex was detected in the lung and whole blood of mice instilled with SEB (fig. 4b). In contrast, no significant EPR signals were observed in the lung of PBS-injected control mice after administration of DTCS and $\mathrm{FeSO}_{4}$ (fig. 4a). The EPR signal of NO-(DTCS) $)_{2}-\mathrm{Fe}^{2+}$ complex was reduced with AG treatment. The EPR signal of NO-(DTCS) $)_{2}-\mathrm{Fe}^{2+}$ complex in both whole blood and lung tissue was increased with AHPP treatment (figs. 4e and f). The increased production of NO when treated with AHPP reflects the amount of $\mathrm{O}_{2}^{-}$and peroxynitrite $\left(\mathrm{ONOO}^{-}\right)$, because $\mathrm{O}_{2}^{-}$ rapidly reacts with $\mathrm{NO}$ to produce $\mathrm{ONOO}^{-}$at almost diffusion rate. In contrast, AHPP did not increase the amount of nitrite/nitrate in Griess assay (figs. 3c and d) because the amount of $\mathrm{ONOO}^{-}$was already counted as nitrate, the decomposited product of $\mathrm{ONOO}^{-}$.

\section{Immunohistochemistry of lung and bronchoalveolar lavage cells from staphylococcal enterotoxin-B instilled mice}

Immunohistochemistry with an anti-iNOS antibody was also used to examine the induction of iNOS protein in lung and BAL cells 3 days after SEBinjection. iNOS staining was observed in macrophages and neutrophils infiltrating the alveoli and alveolar septal walls of the lung injected with SEB (figs. 5a and $b$ ). Positive staining for iNOS was also observed in macrophages and neutrophils of BAL cells from mice instilled with SEB (fig. 5c). Little staining was observed in PBS-injected control lungs (fig. 5d). 

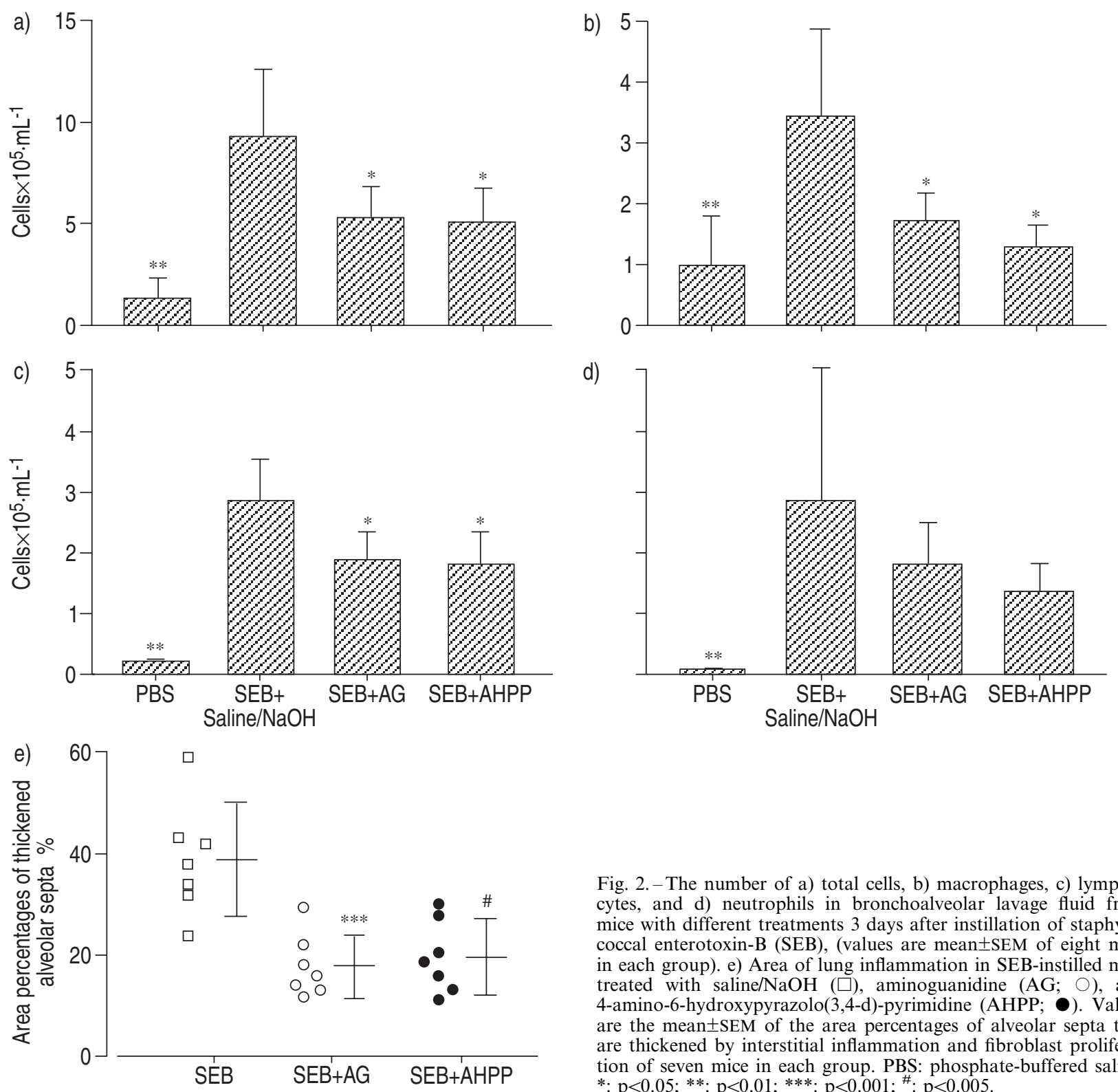

To verify the local production of $\mathrm{ONOO}^{-}$in lung and BAL cells from SEB-instilled mice, the formation of nitrotyrosine, the well-known biomarker of $\mathrm{ONOO}^{-}$-mediated protein nitration, was evaluated by immunohistochemistry. Marked positive staining for nitrotyrosine was observed in macrophages and neutrophils in lung (figs. 5e and f) and BAL cells (fig. 5g). It is of considerable importance that the staining pattern with antinitrotyrosine antibody was similar to that with anti-iNOS antibody, as it indicates that iNOS-derived NO may be converted to $\mathrm{ONOO}^{-}$ at the site of inflamed lung.

Induction of xanthine oxidase/xanthine dehydrogenase activity in the staphylococcal enterotoxin-B instilled mice

The $\mathrm{O}_{2}^{-}$production in this SEB-induced IP model was evaluated and the therapeutic mechanism

Fig. 2.- The number of a) total cells, b) macrophages, c) lymphocytes, and d) neutrophils in bronchoalveolar lavage fluid from mice with different treatments 3 days after instillation of staphylococcal enterotoxin-B (SEB), (values are mean \pm SEM of eight mice in each group). e) Area of lung inflammation in SEB-instilled mice treated with saline/ $\mathrm{NaOH}(\square)$, aminoguanidine (AG; $\bigcirc$ ), and 4-amino-6-hydroxypyrazolo(3,4-d)-pyrimidine (AHPP; $\bigcirc$ ). Values are the mean \pm SEM of the area percentages of alveolar septa that are thickened by interstitial inflammation and fibroblast proliferation of seven mice in each group. PBS: phosphate-buffered saline. *: $\mathrm{p}<0.05 ; * *: \mathrm{p}<0.01 ; * * *: \mathrm{p}<0.001 ;{ }^{\#}: \mathrm{p}<0.005$.

of AHPP was analysed. XO/XD activity from mouse lung, s-BAL fluid, and plasma at various time points after SEB or PBS (control) instillation is shown in figure 6. In the SEB-injected mice, maximal $\mathrm{XO} /$ $\mathrm{XD}$ activity in s-BAL fluid and lung was observed 3 days after instillation. XO/XD activity in s-BAL fluid and plasma of the SEB-instilled mice was significantly greater than that of the control mice on day $3(\mathrm{p}<0.05)$, and an increase in $\mathrm{XO} / \mathrm{XD}$ activity in the lung was greater, though not statistically, than that in control mice. XO/XD activity from mouse s-BAL fluid and plasma was significantly decreased by treatment with AHPP in comparison to control on day 3 (fig. $6, \mathrm{p}<0.05$ ). There was no significant difference between the AHPP treatment and control in the XO/XD activity in the lung, possibly because such activity is difficult to measure in the lung due to the presence of inhibitory compounds. 

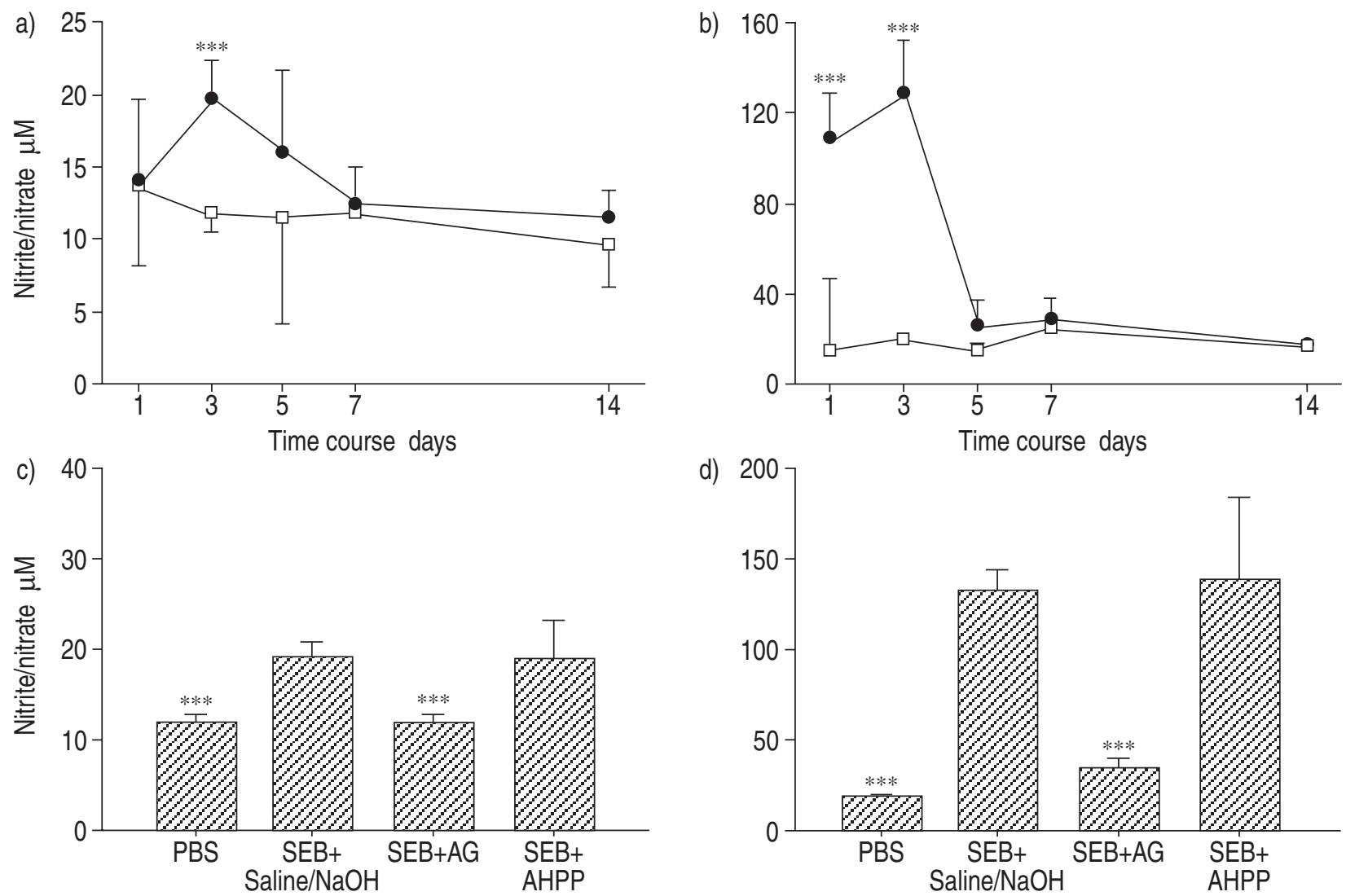

Fig. 3. - The time course of the nitrite/nitrate production in a) bronchoalveolar lavage fluid (BAL) and b) serum. Compared with phosphate-buffered saline (PBS; $\square$ ), nitrite/nitrate formation was increased at day 3 after staphylococcal enterotoxin-B (SEB; $\bullet$ ) injection (PBS-instilled mice: $n=6$; SEB-instilled mice: $n=6$ ). Inhibitory effects of aminoguanidine (AG) and 4-amino-6-hydroxypyrazole (3,4-d)pyrimidine (AHPP) on nitrite/nitrate formation in c) BAL fluid and d) serum on day 3 after SEB administration. Compared with saline/ $\mathrm{NaOH}$ and AHPP, AG inhibited the nitrite/nitrate formation in BAL fluid and serum in SEB-instilled mice (Saline/ $\mathrm{NaOH}$ treated mice: $\mathrm{n}=6$; AG treated mice: $\mathrm{n}=6$; AHPP treated mice: $\mathrm{n}=6$. Values are expressed as mean \pm SEM. ${ }^{* * *}$ : $\mathrm{p}<0.001$.

Time course of inducible nitric oxide synthase and xanthine oxidaselxanthine dehydrogenase messenger ribonucleic acid levels in bronchoalveolar lavage cells from staphylococcal enterotoxin-B instilled mice

Overproduction of $\mathrm{NO}$ and $\mathrm{O}_{2}{ }^{-}$was confirmed via induction of iNOS and XO/XD at the molecular level. iNOS and XO/XD mRNA levels in BAL cells (1, 3, 5, 7, and 14 days after SEB administration) were measured using RT-PCR and compared with those in PBS-instilled mice (fig. 7). Both iNOS and XO/XD mRNA levels increased in the SEB-instilled mice and peaked on day 3. The differences between SEB-instilled mice and PBS-instilled mice on day 3 were significant $(\mathrm{p}<0.05)$.

Inducible nitric oxide synthase-inducing activity and cytokine production in bronchoalveolar lavage fluid from staphylococcal enterotoxin-B instilled mice

To evaluate iNOS-inducing activity, the ability of BAL fluid from SEB-injected mice to induce nitrite/ nitrate production in cell culture medium of RAW 264 cells was analysed. BAL fluid on day 3 after injection of SEB stimulated RAW 264 cells to produce nitrite/ nitrate and this was not observed in BAL fluid from PBS-instilled controls (fig. 8a). The effects of AG and AHPP on pro-inflammatory cytokine levels in s-BAL fluid on day 3 after SEB instillation are shown in figures $8 \mathrm{~b}-\mathrm{d}$. SEB instillation significantly increased TNF- $\alpha$, IL- $1 \beta$, and IFN- $\gamma$ levels in s-BAL fluid in comparison to levels in PBS-instilled controls. Treatment with AG and AHPP significantly suppressed IL-1 $\beta$ levels in the s-BAL fluid of mice instilled with SEB by $50.4 \%$ and $38.3 \%$, respectively. Similarly, treatment with AG and AHPP significantly suppressed IFN- $\gamma$ levels in the s-BAL fluid of mice injected with SEB by $78.6 \%$ and $59.9 \%$, respectively. Though not statistically significant, AG treatment and AHPP treatment also suppressed TNF- $\alpha$ levels.

These results indicate that both $\mathrm{NO}$ and $\mathrm{O}_{2}^{-}$may be involved in the expression of pro-inflammatory cytokines, and both AG and AHPP may act as anti-inflammatory agents via inhibition of proinflammatory cytokine production.

\section{Discussion}

In this study, increased production of $\mathrm{NO}$ and $\mathrm{O}_{2}^{-}$ in a mouse model of autoimmune-associated IP was 

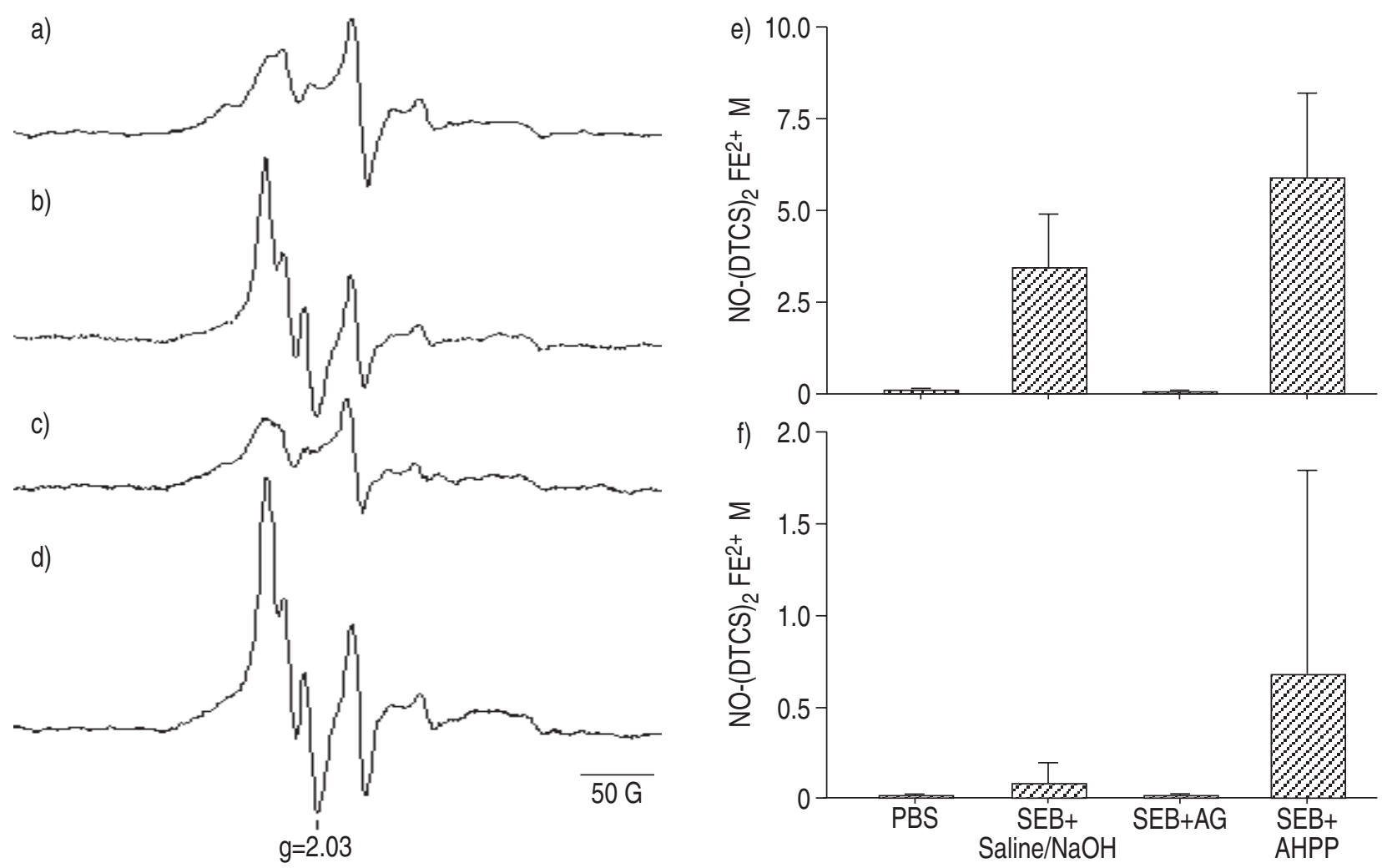

Fig. 4. - In vivo spin-trapping with NO-(N-(dithiocarboxy) sarcosine $)_{2}-\mathrm{Fe}^{2+}\left(\mathrm{NO}-(\mathrm{DTCS})_{2}-\mathrm{Fe}^{2+}\right.$ ) complex formed in mouse lung injected with staphylococcal enterotoxin-B (SEB) by electron paramagnetic resonance (EPR) spectroscopy. EPR spectra observed in mouse lung injected with a) phosphate-buffered saline (PBS), b) SEB with saline/ $\mathrm{NaOH}$ treatment, c) aminoguanidine (AG) treatment, and d) 4-amino-6-hydroxypyrazolo(3,4-d)-pyrimidine (AHPP) treatment. Concentration of NO-(DTCS) $2_{2}-\mathrm{Fe}^{2+}$ in lung and whole blood of PBSinstilled or SEB-instilled mice with saline/NaOH, AG, and AHPP on day 3. Compared with saline/ $\mathrm{NaOH}$ and AHPP, AG inhibited the concentration of NO-(DTCS $)_{2}-\mathrm{Fe}^{2+}$ in whole blood and lung in SEB-instilled mice. g: g-valve; G: Gauss. All data are shown as mean \pm SEM (Saline/ $\mathrm{NaOH}$ treated mice: $\mathrm{n}=3$; AG treated mice: $\mathrm{n}=3$; AHPP treated mice: $\mathrm{n}=3$ ).
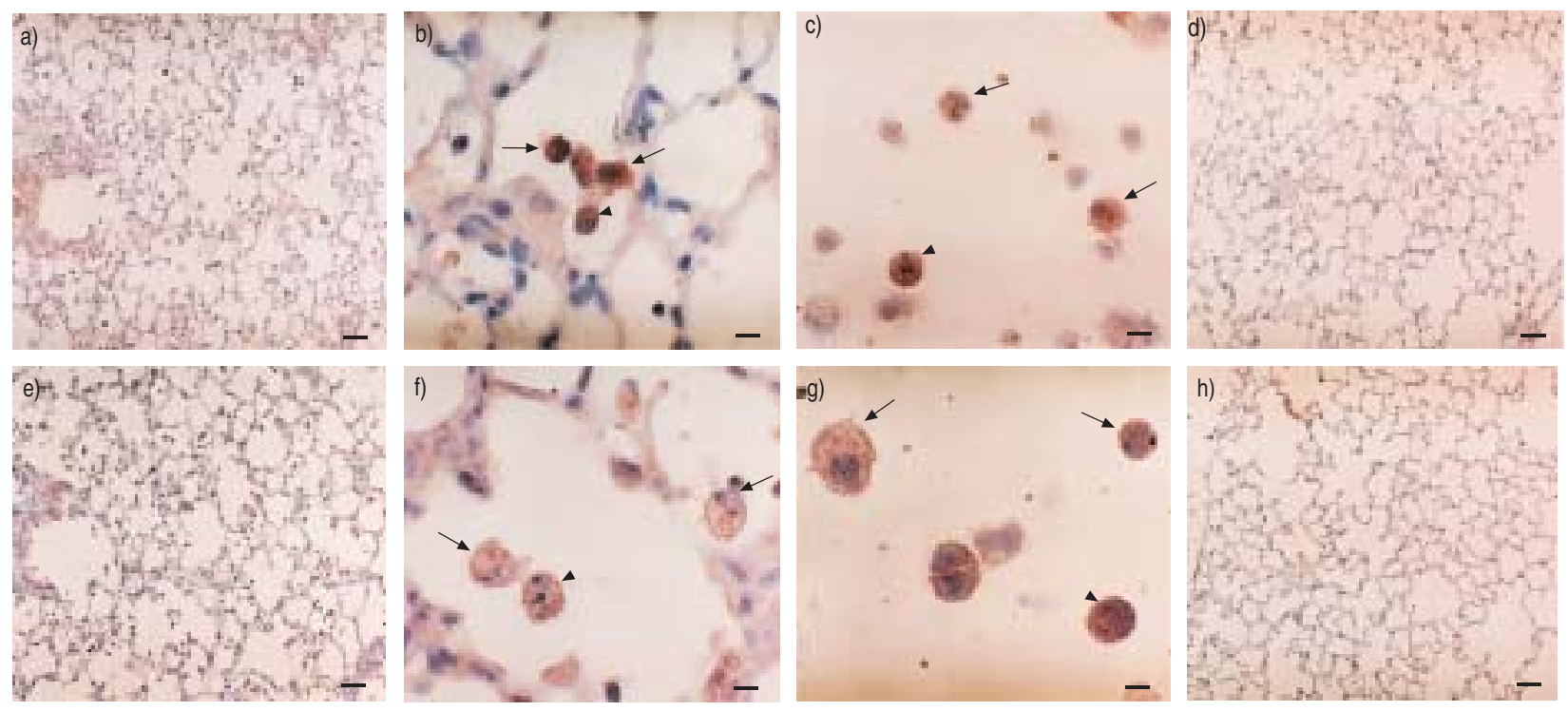

Fig. 5. - Immunohistochemistry of mouse lung and bronchoalveolar lavage (BAL) cells 3 days after injection with staphylococcal enterotoxin-B (SEB); specific antibody is against inducible nitric oxide synthase (iNOS) (a-d) and nitrotyrosine (e-h). Intense iNOSstaining was observed in macrophages (arrows) and neutrophils (arrowheads) infiltrating into alveoli and alveolar septal walls in the SEB-injected lung ( $\mathrm{a}$ and $\mathrm{b}$ ). A positive anti-iNOS antibody reaction was observed in macrophages (arrows) and neutrophils (arrowheads) of BAL cells from mice injected with SEB (c). PBS-injected lung stained with anti-iNOS antibody (d). The same results were obtained by anti-nitrotyrosine antibody (e-h). Internal scale bar: $\mathrm{a}, \mathrm{d}$, e and $\mathrm{h}=50 \mu \mathrm{m}, \mathrm{b}, \mathrm{c}, \mathrm{f}$ and $\mathrm{g}=10 \mu \mathrm{m}$. 

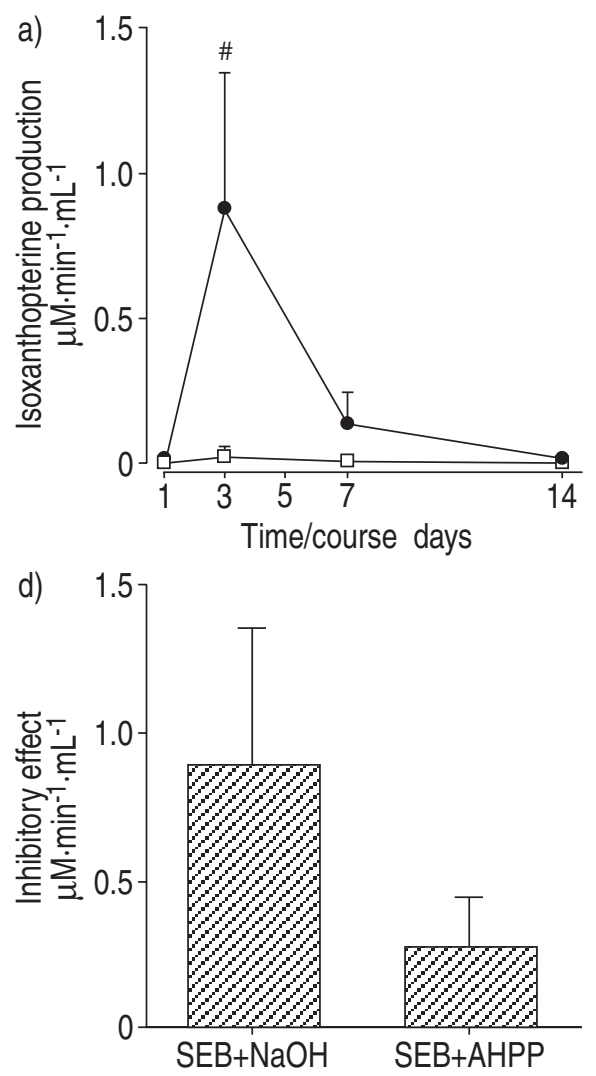

b) 8

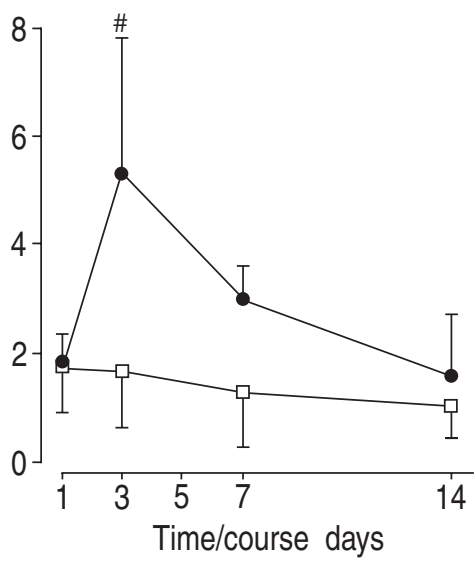

e)

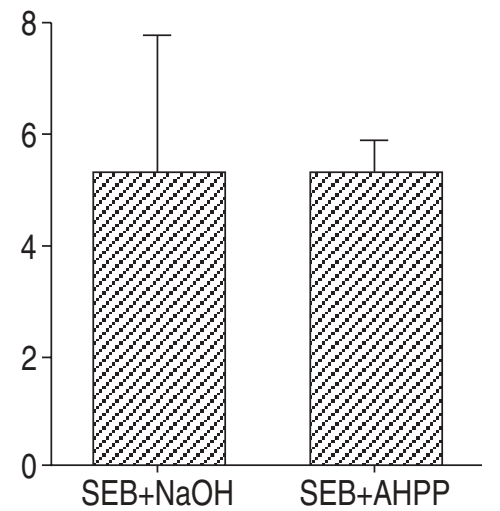

c) 2.5
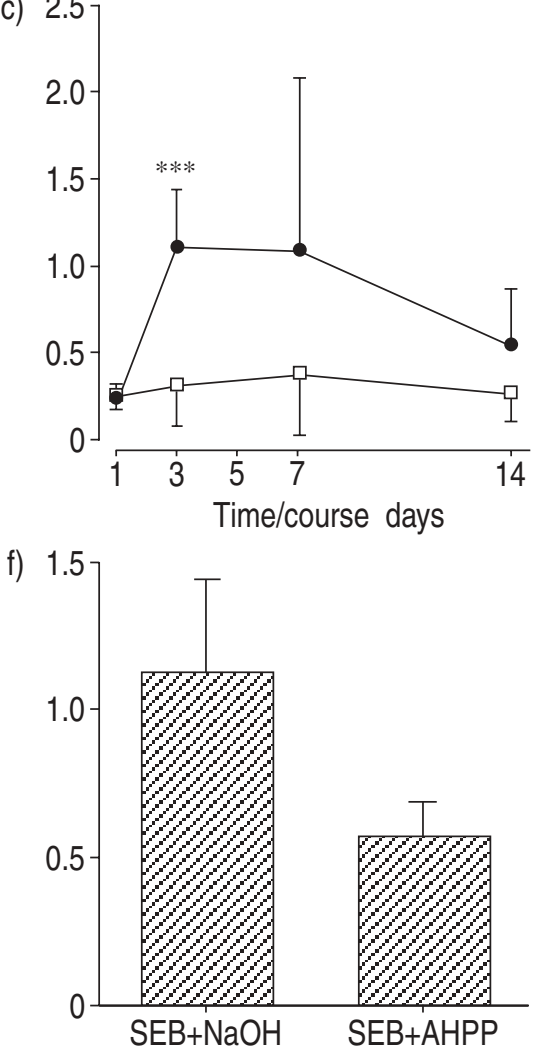

Fig. 6. - Time course of xanthine oxidase/xanthine dehydrogenase (XO/XD) activity in a) the bronchoalveolar lavage (BAL) fluid, b) lung, and c) plasma from staphylococcal enterotoxin-B (SEB)-instilled mice. Compared with phosphate-buffered saline ( $\square)$, SEB ( $)$ increased the XO/XD activity at day 3 after SEB injection. Inhibitory effect of 4-amino-6-hydroxypyrazolo(3,4-d)-pyrimidine (AHPP) on XO/XD activity at day 3 for d) BAL fluid, e) lung, and f) plasma is also shown. Mean \pm SEM values at least five mice in each group. $* * *$ : $<<0.001$; \#: $\mathrm{p}<0.005$.

found. Overproduction of $\mathrm{NO}$ and $\mathrm{O}_{2}^{-}$was closely related to high-level production of TNF- $\alpha$, IL-1 $\beta$ and IFN- $\gamma$ in BAL fluid. Inhibition of $\mathrm{NO}$ and $\mathrm{O}_{2}{ }^{-}$ production by $\mathrm{AG}$ and AHPP (iNOS and $\mathrm{XO}$ inhibitors, respectively) suppressed production of pro-inflammatory cytokines and protected against the development of IP. These results are important in terms of understanding the mechanism of IP, and may provide novel therapeutic approaches to autoimmune diseases-associated IP.

Nitrite/nitrate production was increased in BAL fluid and serum from SEB-injected mice and the generation of NO was detected directly by EPR spectroscopy. Similarly, XO/XD activity was highly upregulated, with increased protein and mRNA levels, and released into the alveolar space in the SEBinjected lung. It has been reported that NO plays an important role in the regulation of cell function and has an anti-inflammatory role in lung injury [21, 22]. At inflamed sites in the lung, however, a high concentration of $\mathrm{O}_{2}$ in the alveolar space and the generation of $\mathrm{O}_{2}^{-}$rapidly convert $\mathrm{NO}$ to RNS, such as $\mathrm{ONOO}^{-}$and nitrogen dioxide $\left(\mathrm{NO}_{2}\right)$. RNS are thought to be important mediators of pulmonary inflammation and are highly toxic to pulmonary cells [20]. In vivo detection of $\mathrm{ONOO}^{-}$is difficult because of its short half-life and high reactivity. However, the increase in the amount of NO-(DTCS $)_{2}-\mathrm{Fe}^{2+}$ complex following AHPP treatment due to the inhibition of $\mathrm{O}_{2}{ }^{-}$ production, is indirect evidence of $\mathrm{ONOO}^{-}$formation in the lung injected with SEB. Moreover, the local production of $\mathrm{ONOO}^{-}$at the site of inflamed lung was verified by immunohistochemistry using an antinitrotyrosine antibody. Both AG and AHPP decreased the number of macrophages, lymphocytes and neutrophils in BAL fluid, and thus reduced the area of the pathological lung tissue damage. These results support the notion that $\mathrm{ONOO}^{-}$mediates lung injury and is a factor in the pathogenesis of SEB-induced IP.

BAL fluid obtained from SEB-injected mice induced iNOS activity in RAW 264 cells. Several pro-inflammatory cytokines are implicated in induced iNOS expression in macrophages. In addition, $\mathrm{XO} /$ $\mathrm{XD}$ expression is regulated by pro-inflammatory cytokines such as IL-1 $\beta$. The XD (low $\mathrm{O}_{2}^{-}$generating activity) is converted into $\mathrm{XO}$ (high $\mathrm{O}_{2}{ }^{-}$generating activity) by processes including thiol oxidation and/or proteolysis. In fact, cytokine (IFN- $\gamma$, IL- $1 \beta$ and TNF- $\alpha$ ) levels in the BAL fluid from SEB-injected mice were markedly elevated compared with levels in control mice. These findings suggest that IFN- $\gamma$ produced from SEB-activated Th1 cells or IL-1 $\beta$ and TNF- $\alpha$ produced from SEB-activated inflammatory cells stimulate alveolar exudate macrophages to induce iNOS gene expression. In addition, inhibition of pro-inflammatory cytokine production by $\mathrm{AG}$ and 
a)
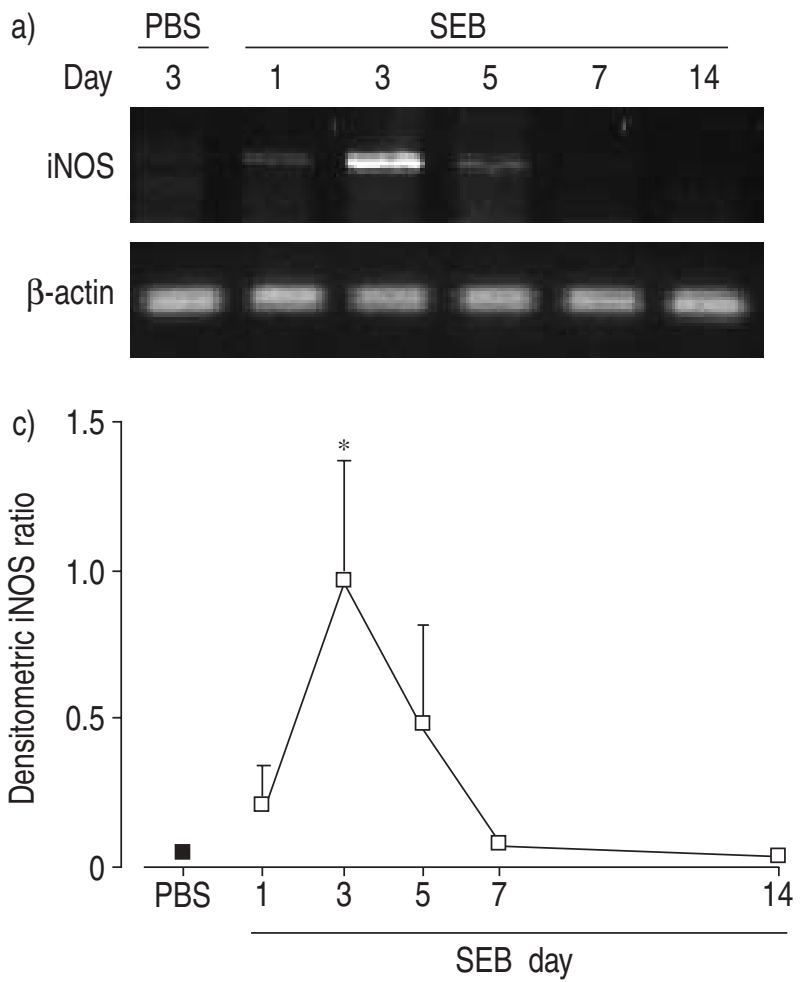

b)
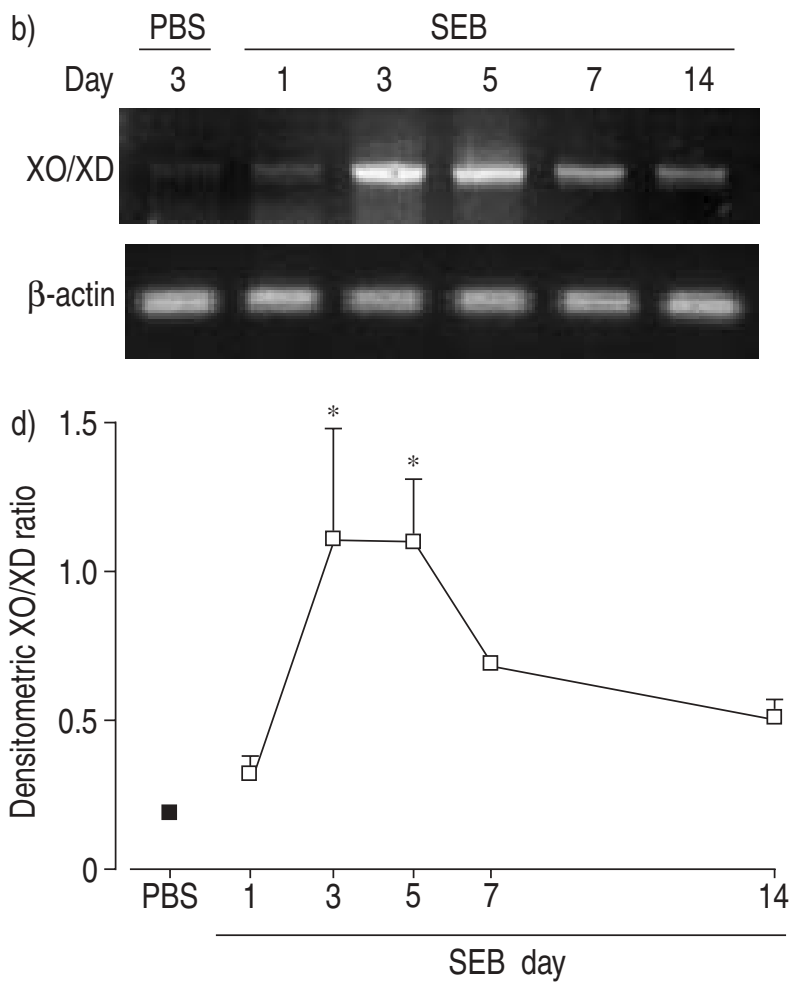

Fig. 7. - Messenger ribonucleic acid (mRNA) levels in the bronchoalveolar lavage (BAL) cells from staphylococcal enterotoxin-B (SEB)instilled mice: a) inducible nitric oxide synthase (iNOS); b) xanthine oxidase/xanthine dehydrogenase (XO/XD). BAL cells were obtained from three mice on day 3 after phosphate-buffered saline (PBS) instillation or on days 1, 3, 5, 7, or 14 after SEB instillation. Time course of c) iNOS and d) XO/XD. Densitometric ratio of iNOS and XO/XD mRNA levels are expressed as mean \pm SEM levels against $\beta$-actin mRNA levels for each sample. *: $\mathrm{p}<0.05$.

AHPP indicates that $\mathrm{NO}$ and $\mathrm{O}_{2}^{-}$upregulate expression of these cytokines. A positive feedback loop may be presumed between iNOS and XO, and cytokine induction, causing overproduction of RNS and ROS in the lung of SEB-injected mice.

Transcription factors nuclear factor- $\kappa \mathrm{B}(\mathrm{NF}-\kappa \mathrm{B})$ and activation protein 1 (AP-1) induce gene expression, which mediates the immune response, stress response, cell growth, and cell survival. Activation of $\mathrm{NF}-\kappa \mathrm{B}$ and/or AP-1 in vivo is necessary for the production of early response cytokines, such as TNF$\alpha$, IL-1 $\beta$, iNOS, and IFN- $\gamma$ in lung inflammation
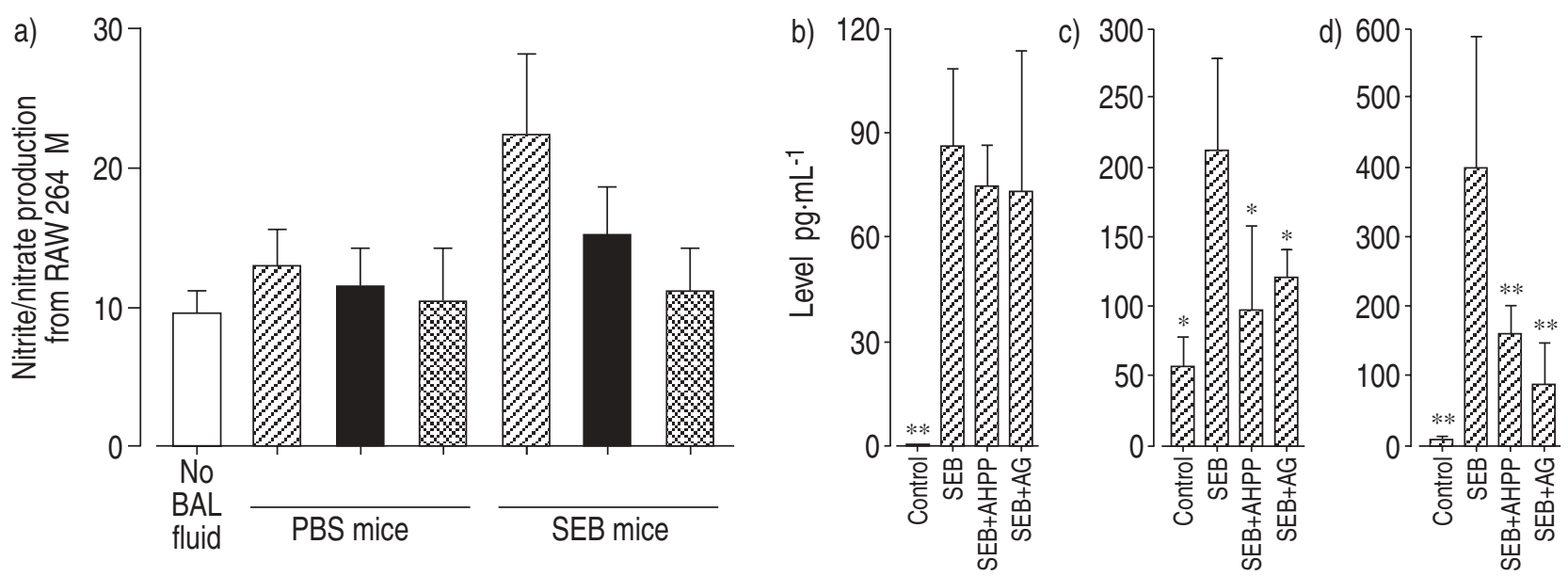

Fig. 8. - a) Nitric oxide synthase (NOS)-inducing activity of bronchoalveolar lavage (BAL) fluid in RAW 264 cells in culture. Inducible NOS induction was assessed by measurement of the nitrite/nitrate released in the culture after stimulation with serially diluted s-BAL fluid $(\mathbb{Q} 1 \times 2 ; \mathbf{\square}: 1 \times 5 ; \mathbf{Q}: 1 \times 10)$. Mean $\pm \operatorname{SEM}(\mathrm{n}=5)$ values are shown. b) Tumour necrosis factor $(\mathrm{TNF})-\alpha ; \mathrm{c})$ interleukin- $1 \beta$ (IL-1 $\beta)$; d) interferon- $\gamma$ (IFN- $\gamma)$. Cytokine concentrations detected in BAL fluid by enzyme-linked immunosorbant assay. BAL fluid samples were obtained from mice injected with phosphate-buffered saline (PBS) or staphylococcal enterotoxin-B (SEB) and treated with saline/ $\mathrm{NaOH}$, aminoguanidine (AG), or 4-amino-6-hydroxypyrazolo(3,4-d)-pyrimidine (AHPP) for 3 days after injection. Mean \pm SEM values of at least six mice in each group. ${ }^{* *}: \mathrm{p}<0.01 ; * \mathrm{p}<0.05$ versus mice injected with SEB alone. 
$[23,24] . \mathrm{NF}-\kappa \mathrm{B}$ and AP-1 are known redox-sensitive transcription factors and are activated by ROS and RNS. Various studies have been conducted on the mechanisms of ROS- and RNS-mediated activation of the NF- $\kappa$ B and AP-1 pathway. Signals from cytokines are transduced along the signalling pathway, from upstream protein kinase cascades to the downstream transcription factors. ROS and RNS directly activate cytokine receptors via dimerization of the receptor or activation of receptor tyrosine kinase (RTK), it activates a protein-kinase cascades, such as the MAP kinase (MAPK) and $I \kappa B$ kinase (IKK) [25]. Numerous papers argue that antioxidants suppress cytokine gene induction via inhibition of $\mathrm{NF}-\kappa \mathrm{B}$ and/or AP-1 activation [26]. Therefore, the authors suggest that the effectiveness of treatment with AG or AHPP against SEB-induced lung inflammation and fibrosis resides in the ability of these agents to inhibit $\mathrm{NF}-\kappa \mathrm{B}$ and $\mathrm{AP}-1$ activation and thereby to suppress the production of the proinflammatory cytokines. The results of this study suggest that inhibition of $\mathrm{NO}$ and $\mathrm{O}_{2}^{-}$production by $\mathrm{AG}$ and AHPP not only reduces the direct toxicity of free radicals but also decreases free radical-mediated cytokine production.

Previous studies of both human and murine macrophages indicate that NO plays a regulatory role in TNF- $\alpha$ and IL-1 $\beta$ production [20, 27, 28]. Endogenous NO was reported to upregulate TNF- $\alpha$ production in U937 cells [28] and alveolar macrophages [27]. However, under certain conditions, NO may downregulate cytokine production [20, 29]. This discrepancy between studies is still not explained. Concentration dependence of $\mathrm{NO}$ on the regulation of NF- $\kappa \mathrm{B}$ has been reported [30]. Low levels of $\mathrm{NO}$ activated the $\mathrm{NF}-\kappa \mathrm{B}$ pathway via the activation of IKKs. In contrast, high levels of NO partially inhibited $\mathrm{NF}-\kappa \mathrm{B}$ via S-nitrosylation of ${ }^{62} \mathrm{Cys}$ of $\mathrm{p} 50$ subunit, which eliminates NF- $\mathrm{B}$ DNA-binding capacity. Growing evidence suggests that RNS, such as $\mathrm{ONOO}^{-}$or $\mathrm{NO}_{2}$, may activate NF- $\mathrm{BB}$. Thus, not all, but many of the cytotoxic effects of NO may be mediated by $\mathrm{ONOO}^{-}$, not by NO itself. Therefore, the double-edged function of NO in cytokine-inducing activity may depend on the source and level of NO, the cell types, redox status, and the intra-/extracellular status of ROS. Identification of the role of $\mathrm{NO}$ in SEB-induced tissue injury will therefore provide insight into the delicate balance.

To conclude, superantigens acting on $\mathrm{V} \beta 8^{+} \mathrm{T}$-cells upregulated nitric oxide and super oxide anion generation and pro-inflammatory cytokine production in inflammatory sites in this mouse model of autoimmune-associated interstitial pneumonia. Nitric oxide interacted with super oxide anion to generate perioxynitrite, an important mediator of pulmonary inflammation in this model. The production of proinflammatory cytokines was modulated by endogenous nitric oxide and super oxide anion or their reaction product, perioxynitrite, which might participate in the injury process of interstitial pneumonia in this model. Moreover, inhibitors of inducible nitric oxide synthase and xanthine oxidase may be potential therapeutic agents against alveolitis and/or fibrosis in interstitial pneumonia.

\section{References}

1. Kelly C, Gardiner P, Pal B, Griffiths I. Lung function in primary Sjögren's syndrome: a cross sectional and longitudinal study. Thorax 1991; 46: 180-183.

2. Schwarz MI, Sutarik JM, Nick JA, Leff JA, Emlen JW, Tuder RM. Pulmonary capillaritis and diffuse alveolar hemorrhage. A primary manifestation of polymyositis. Am J Respir Crit Care Med 1995; 151: 2037-2040.

3. Tazelaar HD, Viggiano RW, Pickersgill J, Colby TV. Interstitial lung disease in polymyositis and dermatomyositis. Am Rev Respir Dis 1990; 141: 727733.

4. Paliard X, West SG, Lafferty LA, et al. Evidence for the effects of a superantigen in rheumatoid arthritis. Science 1991; 253: 325-329.

5. Crystal RG, Bitterman PB, Rennard SI, Hance AJ, Keogh BA. Interstitial lung diseases of unknown cause. Disorders characterized by chronic inflammation of the lower respiratory tract. $N$ Engl J Med 1984; 310: 235-244.

6. Pullen AM, Wade T, Marrack P, Kappler JW. Identification of the region of $\mathrm{T}$ cell receptor $\beta$ chain that interacts with the self-superantigen Mls- $1^{\text {a }}$. Cell 1990; 61: 1365-1374.

7. Andrews BS, Eisenberg RA, Theofilopoulos AN, et al. Spontaneous murine lupus-like syndromes. Clinical and immunopathological manifestations in several strains. J Exp Med 1978; 148: 1198-1215.

8. Shinbori T, Matsuki M, Suga M, Kakimoto K, Ando $\mathrm{M}$. Induction of interstitial pneumonia in autoimmune mice by intratracheal administration of superantigen staphylococcal entertoxin B. Cell Immunol 1996; 174: 129-137.

9. Fujiki M, Shinbori T, Suga M, Miyakawa H, Ando M. Role of T cells in bronchoalveolar space in the development of interstitial pneumonia induced by superantigen in autoimmune-prone mice. Am J Respir Cell Mol Biol 1999; 21: 675-683.

10. Vladutiu AO. Role of nitric oxide in autoimmunity. Clin Immuno Immunopath 1995; 76: 1-11.

11. Lowenstein CJ, Dinerman JL, Snyder SH. Nitric oxide: a physiologic messenger. Ann Intern Med 1994; 120: 227-237.

12. Stuehr DJ, Marletta MA. Mammalian nitrate biosynthesis: mouse macrophages produce nitrite and nitrate in response to Escherichia coli lipopolysaccharide. Proc Natl Acad Sci 1985; 82: 7738-7742.

13. McCartney-Francis N, Allen JB, Mizel DE, et al. Supression of arthritis by an inhibitor of nitric oxide synthase. J Exp Med 1993; 178: 749-754.

14. Weinberg JB, Granger DL, Pisetsky DS, et al. The role of nitric oxide in the pathogenesis of spontaneous murine autoimmune disease: increased nitric oxide production and nitric oxide synthase expression in MRL-lpr/lpr mice, and regulation of spontaneous glomerulonephritis and arthritis by orally administered $\mathrm{N}^{\mathrm{G}}$-monomethyl-L-arginine. J Exp Med 1994; 179: 651-660.

15. Sarawar SR, Blackman MA, Doherty PC. Superantigen shock in mice with an inapparent viral infection. J Infect Dis 1994; 170: 1189-1194. 
16. Florquin S, Amraoui Z, Dubois C, Decuyper J, Goldman M. The protective role of endogenously synthesized nitric oxide in staphylococcal enterotoxin B-induced shock in mice. J Exp Med 1994; 180: 11531158.

17. Green LC, Wagner DA, Glogowski J, Skipper PL, Wishnok JS, Tannenbaum SR. Analysis of nitrate, nitrite, and $\left[{ }^{15} \mathrm{~N}\right]$ nitrate in biological fluids. Anal Biochem 1982; 126: 131-138.

18. Doi K, Akaike T, Horie H, et al. Excessive production of nitric oxide in rat solid tumor and its implication in rapid tumor growth. Cancer 1996; 77: 1598-1604.

19. Akaike T, Ando $\mathrm{M}$, Oda $\mathrm{T}$, et al. Dependence on $\mathrm{O}_{2}{ }^{-}$ generation by xanthine oxidase of pathgenesis of influenza virus infection in mice. J Clin Invest 1990; 85: 739-745.

20. Akaike T, Noguchi Y, Ijiri S, et al. Pathogenesis of influenza virus-induced pneumonia: involvement of both nitric oxide and oxygen radicals. Proc Natl Acad Sci 1996; 93: 2448-2453.

21. Suga M, Okamoto T, Ando M. Nitric oxide and interstitial lung disease. Curr Opin Pulm Med 1998; 4: $251-255$.

22. Cantin AM, North SL, Fells GA, Hubbard RC, Crystal RG. Oxidant-mediated epithelial cell injury in idiopathic pulmonary fibrosis. J Clin Invest 1987; 79: $1665-1673$.

23. Schreck R, Albermann K, Baeuerle PA. Nuclear factor- $\mathrm{kB}$ : an oxidative stress-responsive transcription factor of eukaryotic cells. Free Radic Res Commun 1992; 17: 221-237.
24. Gurujeyalakshmi G, Wang Y, Giri SN. Taurine and niacin block lung injury and fibrosis by downregulating bleomycin-induced activation of transcription nuclear factor- $\mathrm{\kappa B}$ in mice. $J$ Pharmacol Exp Ther 2000; 293: 82-90.

25. Janssen-Heininger YM, Poynter ME, Baeuerle PA. Recent advances towards understanding redox mechanisms in the activation of nuclear factor $\kappa \mathrm{B}$. Free Radic Biol Med 2000; 28: 1317-1327.

26. Nathens AB, Bitar R, Davreux C, et al. Pyrrolidine dithiocarbamate attenuates endotoxin-induced acute lung injury. Am J Respir Cell Mol Biol 1997; 17: 608616.

27. Kuo HP, Wang $\mathrm{CH}$, Huang $\mathrm{KS}$, et al. Nitric oxide modulates interleukin- $1 \beta$ and tumor necrosis factor- $\alpha$ synthesis by alveolar macrophages in pulmonary tuberculosis. Am J Respir Crit Care Med 2000; 161: 192-199.

28. Yan L, Wang S, Rafferty SP, Wesley RA, Danner RL. Endogenously produced nitric oxide increases tumor necrosis factor- $\alpha$ production in transfected human U937 cells. Blood 1997; 90: 1160-1167.

29. Persoons JHA, Schornagel K, Tilders FFH, Vente J, Berkenbosch F, Kraal G. Alveolar macrophages autoregulate IL-1 and IL-6 production by endogenous nitric oxide. Am J Respir Cell Mol Biol 1996; 14: 272278.

30. Umansky V, Hehner SP, Dumont A, et al. Costimulatory effect of nitric oxide on endothelial $\mathrm{NF}-\kappa \mathrm{B}$ implies a physiological self-amplifying mechanism. Eur J Immunol 1998; 28: 2276-2282. 